\title{
Media Pembelajaran Mobuya untuk Pembelajaran Keragaman Budaya
}

\section{Tri Syamsijulianto*}

Pendidikan Guru Sekolah Dasar Sekolah Tinggi Keguruan dan Ilmu Pendidikan Melawi

\begin{abstract}
Abstrak
Tujuan penelitian untuk mengetahui penggunaan media pembelajaran Mobuya pada pembelajaran keragaman budaya. Batasan masalah dari penelitian ini adalah berupa penggunaan media pembelajaran Mobuya (Monopoli Berbasis Budaya) di Sekolah Dasar Negeri 02 Beduai. Metode yang di gunakan oleh peneliti dalam penelitian ini adalah metode penelitian tindakan kelas (PTK), penelitian tindakan kelas yang dilaksanakan oleh peneliti ini dilakukan dalam dua kali pertemuan. Subjek dari penelitian ini adalah siswa sekolah dasar negeri 02 Beduai dengan jumlah sampel 24 orang. Hasil uji coba lapangan pada media pembelajaran Mobuya di peroleh persentase sebesar 95, 83\%. Dilihat dari presentases rata-rata dari penggunaan media pembelajaran Mobuya untuk pembelajaran keragaman budaya didapatkan nilai rata-rata pada tes I 58,70 dan tes II diperoleh 68,04, terlihat ada perubahan hasil dari pelaksanaan pembelajaran dengan menggunakan media pembelajaran Mobuya. Dengan media pembelajaran mobuya juga mampu memberikan keterampilan, sikap, sehingga mampu meningkatkan daya fantasi peserta didik. Melalui media pembelajaran mampu meningkatkan kesatuan dan persatuan. Peserta didik lebih mengenal kebudayaannya.
\end{abstract}

Kata Kunci:

Media Pembelajaran Mobuya, Pembelajaran

Keragaman

BudayaSiswa

\begin{abstract}
The purpose of the study is to understand the use of media learning on cultural diversity. The boundary problem of this study is the use of a learning media Mobuya (Monopoli Based Culture) at a elementary school 02 Beduai. The method used by research in this study is a class-action study method, the class action research carried out by researchers carried out in two meeting. The subject of this study is 02 of elementary school with a total 24 samples. Field test results on learning have a percentage of $95,83 \%$. Based on the average percentage of the Mobuya learning media for culturally diverse learninf got an average value on the first test of 58,70 and the second test was obtained 68,04, there is change in the performance of Mobuya learning media. With the Mobuya learning media it is also able to provide attitude skills and thus be able to improve the fantasy power of learner through.mengenal kebudayaannya.
\end{abstract}

Keywords:

Learning Media Mobuya, Diversity Learning

\footnotetext{
* Corresponding author. 


\section{PENDAHULUAN}

Pendidikan dilakukan dalam rangka pemberian pengetahuan. salah satu cara yang dapat dilakukan dengan mendukung perkembangan ilmu pengetahuan (Raharjo, 2015). Lebih lanjut Maulana (2016) menjelaskan bahwa ilmu pengetahuan sebagaimana seiring dengan perkembangan waktu masyarakat dituntut menguasai berbagai hal sehingga dapat meningkatkan keterampilan hidup. Hal ini sejalan dengan tujuan pendidikan sebagai mana tertuang dalam UU No. 20 Tahun 2003 tentang sistem pendidikan nasional pasal 1 menyatakan bahwa:

"Pendidikan adalah usaha sadar dan terencana untuk mewujudkan suasana belajar dan proses pembelajaran agar peserta didik secara aktif mengembangkan potensi dirinya untuk memiliki kekuatan spiritual keagamaan, pengendalian diri, kepribadian, kecerdasan, akhlak mulia, serta keterampilan yang diperlukan dirinya, masyarakat, bangsa dan Negara".

Agar menjadikan pendidikan lebih bermakna serta mewujud manusia yang beraklak mulia diperkulakan berbagai cara, sehingga aspek terpenting dalam mempengaruhi kemajuan bangsa ini dapat terwujud. Pemerintah melalui kementerian pendidikan dan kebudayaan terus berupaya menjadi pendidikan di Indonesia dapat mengikuti arah perkembangan dunia pendidikan. Salah satu upaya yang dilakukan oleh pemerinta dalam mengikuti perkembangan dunia pendidikan berupakan menerapkan pembelajaran tematik.

Pembelajaran tematik merupakan salah sapembelajaran yang dilakukan dengan memadukan beberapa kompetensi kedalam satu tema dengan mengintregasikan berbagai konsep dasar sehingga peserta didik tidak belajar secara parsial namun memberikan makna utuh ini tercermin pada berbagai tema (Utami (2015). Pembelajaran tematik melibatkan peserta didik dalam pembelajaran dikelas untuk meningkatkan kompetensi yang dimilikinya. Lebih lanjut Sukini (2012) pembelajaran tematik lebih menekankan kepada keterlibatan peserta didik pada pembelajaran aktif sehingga dapat memperoleh pengalaman langsung dan terbiasa menemukan sendiri berbagai pengetahuan yang dipelajarinya.

Tujuan dari pembelajaran tematik yaitu untuk mempelajari pengetahuan dan mengembangkan berbagai kopetensi dalam satu tema pembelajaran, serta mengembangkan aspek berbahasa menjadi lebih baik dan meningkatkan karakter peserta melalui nilai budi pekerti sesuai dengan kondisi nyata (Primasari, 2017). Pembelajaran tematik memberikan makna bagi peserta didik dalam meningkatkan aktivitas serta partisipasi aktif pada pembelajaran di kelas, keterampilan aplikatif peserta didik dalam pembelajaran. Pembelajaran tematik dirancang dalam rangka meningkatkan hasil belajar sehingga lebih optimal dan maksimal dengan mengangkat pengalaman peserta didik yang mempunyai jaringan dari berbagai aspek kehidupannya dan pengetahuannya (Kadir \& Asrorah, 2014). Jadi, pembelajaran tematik yang diterapkan disekolah dasar hendaknya memberikan pembelajaran yang bermakna dalam konteks bahwa pembelajaran ini bukan teacher centered lagi tetapi sudah mengarah kepada student centered.

Pembelajaran yang berpusat kepada siswa merupakan salah satu prinsip dari pembelajaran tematik. Hal ini sejalan dengan Puspita (2016) bahwa pembelajaran tematik mencerminkan pembelajaran bermakna serta berpusat kepada peserta didik diterapkan dalam berbagai tema sehingga tidak hanya belajar konsep secara parsial tetapi dilaksanakan dengan utuh. Guru sebagai pioner dalam pembelajaran dituntut untuk memiliki variasi dalam menerapakan pembelajaran sehingga prinsip dari pembelajaran tematik itu dapat tercapai, salah satunya dengan menerapkan media pembelajaran dengan baik (Hartati, Artayasa, \& Lestari ( 2014). Jadi, langkah terbaik dalam menciptakan pembelajaran tematik yang menyenangkan, bermakna dan berpusat pada peserta didik yaitu dengan menciptakan media pembelajaran yang menyenangkankan serta mengarah kepada simulasi pembelajaran.

Fakta yang terjadi pada pembelajaran tematik bahwa pembelajran yang diajar masih monoton. Llebih lanjut hasil temuan dari Macdonald (2014) juga menjelaskan hal sering akali terjadi pada proses pembelajaran tematik berupa peserta didik kurang menyukai kontek yang dibelajarkan pada pembelajaran karena konten pembelajaran tematik yang diajarkan kurang menyenangkan. Berikutnya, hasil temuan dari Retnawati \& Munadi (2017) menunjukan bahwa pada prose pembelajaran tematik hal sering kali dialami oleh guru berupa hambatan dalam memilih tema, guru mendapatkan permasalahan dalam mengelola waktu pelajaran serta ketersediaan fasilitas belajar itu masih terbatas. Pembelajaran yang terjadi karena pembelajaran tematik dibelajarkan secara keseluruhan dilihat melalui berbagai tema (Utami, 2015). Lebih lanjut Sukini (2012) kurang keterlibatan peserta didik pada pembelajaran sehingga belajar tidak menemukan pengetahuan sendiri dari yang dipelajarinya. Sehingga diperlukan pembelajaran yang mampu menumbuhkan kembangkan pengetahuan dan pembelajaran yang menyenangkan.

Berdasarkan penuturan yang diberikan oleh guru kelas IV SDN 02 Beduai guru jarang menggunakan media pembelajaran karena keterbatasanan sarana dan prasana yang ada sehingga guru tidak pernah membuat media pembelajaran pada proses pembelajaran. Selain terbatasnya sarana dan prasarana serta kurang memadai ditambah dengan perlengkapan media tidak tersedia. Selain itu 
permasalahan lain yang kerap kali dialami guru di saat proses pembelajaran dikelas berupa kurang adanya inovasi yang dilakukan dalam merancang membuat media pembelajaran yang tidak memiliki biaya terlalu besar untuk membuat media pembelajaran yang menyenangkan. Kurang adanya inovasi guru dalam melaksanakan proses tersebut sehingga menciptakan pembelajaran yang bermakna.

Solusi yang ditawarkan oleh peneliti dengan media pembelajaran menggunakan permainan monopoli berbasis budaya. Sejalan dengan hal tersebut Halloran, et al. (2017) Salah satu metode yang dapat digunakan sebagai alat pengajaran, yang sering digunakan untuk mencoba melibatkan para siswa sepenuhnya dalam belajar berupa penggunaan permainan ataupun simulasi. Sehubungan dengan hal tersebut D'Astous \& Gagnon (2007) peneliti mengclaim bahwa permainan papan seperti monopoli dapat dimainkan dan dimanfaatkan untuk media pembelajaran yang menyenangkan karena mampu meningkat pemahaman peserta didik sehingga memberikan siswa pemahaman lebih lama. Selain itu game dengan menggunakan papan monopoli juga dapat dikembangkan dalam bentuk media pembelajaran monopoli berbasis budaya. Sejalan dengan itu menurut Park (2017) menjelaskan permainan papan dapat menunjukan bahwa dengan bermain bersama-sama dapat meningkatkan keterampilan sosial peserta didik, selain itu media ini juga mampu memberikan pembelajaran dua arah.

Media pembelajaran Mobuya menjadi solusi yang solutif dalam meningkatkan kemampuan peserta didik pada proses pembelajaran, karena menggabungkan beberapa konsep kedalam satu media pembelajaran. Peserta didik dapat mengenalkan budaya melalui belajar sambil bermain, berpikir kritis, belajar yang menyenangkan. Lebih lanjut, Oktavianti \& Ratnasari (2017) penerapan monopoli budaya pada pembelajaran tematik itu mengajarkan kepada peserta didik untuk dapat belajar pada lingkungan individu dan kelompok dengan tujuan dapat menggali dan menemukan konsep serta makna materi itu sendiri. Mobuya dapat memberikan kontribusi yang positif dalam pengajaran tentang keberagaman budaya bangsaku serta memiliki dampak yang cukup luas untuk mengenalkan budaya daerah yang belum diketahui, serta Mobuya mampu mebelajarkan peserta didik sesuai dengan tuntutan pembelajaran diera modern ini.

Adapun penelitian yang relevan dilakukan oleh Oktavianti \& Ratnasari, (2017) permainan monopoli ini dinyatakan layak untuk digunakan sebagai media pembelajaran dilihat dari hasil validasi oleh beberapa ahli materi dengan klasifikasi sangat layak untuk digunakan sebagai media pembelajaran. Selain itu juga, Selain dari penelitian yang di lakukan di atas ada juga penelitian yang dilakukan oleh Suciati (2015) Hasil penelitian bahwa hasil validasi media pembelajaran Monosa layak digunakan, setelah dilakukan revisi berdasrkan uji ahli, media Monosa diujicoba pada lingkup kelas kecil, didapatlah hasil bahwa media Monosa efektif, efisien, dan terdapat daya tarik bagi pengguna. Penelitian yang dilakukan oleh Afifurrahman (2015) hasil dari pre-test dan post-test yang dilakukan pada kelas kontrol dan kelas eksperimen menggunakan analisis data uji tes thitung diperoleh adalah 4,121 dengan menggunakan tabel distribusi uji-t dengan taraf signifikan 5\% diperoleh $t$ tabel adalah 2,110, dengan demikian Ho ditolak dan Ha diterima, sehingga simpulan dari penelitian ini adalah layak untuk digunakan.

Uraian latar belakang ini menunjukan bahwa media pembelajaran Mobuya sangat perlu untuk dikembangkan sehingga dapat menjadi alternatif bagi guru dalam memberikan pembalajaran bermakna pada peserta didik dengan bermain peserta didik akan lebih memahami pembalajarannya. Sehingga media pembelajaran pada dunia pendidikan dengan melibat semua aspek ini dapat memberikan dampak positif kepada peserta didik, oleh karena itu peneliti ingin mengembang media pembelajaran dengan judul "Media Pembelajaran Mobuya Untuk Pembelajaran Keragaman Budaya".

\section{METODE PENELITIAN}

Sebagai upaya mencari pembuktian dan solusi dari masalah yang diangkat dalam penelitian ini, peneliti telah menentukan dan merancang desain penelitian yaitu dengan metode Penelitian Tindakan Kelas (PTK) merupakan suatu pencermatan terhadap kegiatan yang sengaja dimunculkan, dan terjadi dalam suatu kelas. Menurut Sanjaya (2013: 149) Penelitian Tindakan Kelas (PTK) adalah Proses pengkajian masalah pembelajaran di dalam kelas melalui refleksi diri dan upaya untuk memecahkan dengan cara melakukan berbagai tindakan yang terencana dalam situasi nyata menganalisis setiap pengaruh dari tindakan tersebut.

Subjek Penelitian Tindakan Kelas ini adalah peserta didik kelas IV SDN 02 Beduai, Peserta didik yang menjadi subjek adalah Peserta didik di kelas IV SDN 02 Beduai yang berjumlah 24 orang pada semester ganjil tahun pelajaran 2018/ 2019, sedangkan objek dari penelitian adalah dapat media pembelajaran Mobuya untuk pembelajaran keragaman budaya di kelas IV SDN 02 Beduai Kabupaten Sanggau. Penelitian yang akan di lakukan di SDN 02 Beduai adalah dengan metode penelitian kolaboratif dan disusun dengan metode penelitian kuantitatif deskriftif. 
Menurut Dinata (2010: 221) Hasil analisis disajikan dalam bentuk tabel dan untuk memperoleh hasil analisis yang digunakan sebagai bahan untuk melakukan perencanaan lebih lanjut dalam siklus selanjutnya dan teknik analisis data pada lembar observasi akan dijelaskan dengan menggunakan rumus sebagai berikut:

Persentase keaktifan $=\frac{\text { [umlah keseluruhan siklus }}{\text { Iumlah pebelajar }} \times 100 \%$

Dengan demikian dapat kita ketahui sejauh mana menumbuhnya aktivitas pebelajar yang dicapai dalam proses pembelajaran.

Arikunto (2013 : 36-37) Observasi kemampuan pembelajar mengajar dapat diukur dengan menggunakan rumus berikut:

Kemampuan pembelajar mengajar $=\frac{\text { rerata tiap item setiap siklus }}{\text { banyaknya indikator }} \times 100 \%$

Menurut Sudjana (dalam Giarthy 2012 : 58) Adapun teknik analisis data untuk hasil belajar pebelajar dengan menggunakan perhitungan rata-rata (mean) kelas sebagai berikut:

$$
X=\frac{\text { Nilai keseluruhan pebelajar }}{\text { Jumlah Pebelajar }} \times 100
$$

Indikator keberhasilan dari penelitian ini adalah jika aktivitas pebelajar dan keterampilan pembelajar mengajar pada mata pelajaran IPS mengalami pertumbuhan dengan menerapkan metode role playing dikelas IV SDN 02 Beduai. PTK ini dikatakan berhasil apabila aktivitas belajar dan kemampuan pembelajar mengajar tergolong kedalam kategori baik dengan kriteria baik dengan persentase baik dengan persentase $71-85 \%$ dengan persentase jumlah siswa aktif di dalam proses pembelajaran berjumlah 17 orang. Kriteria kategori ini mengacu pada Arikunto (2013:245) mengklasifikasikan kriteria keberhasilan pada pembelajaran adalah sebagai berikut:

Tabel 1. Percentase Kriteria Keberhasilan

\begin{tabular}{|c|c|c|}
\hline No & Persentase (\%) & Kualifikasi \\
\hline 1 & $\leq 40$ & Sangat kurang \\
\hline 2 & $41-59$ & Kurang \\
\hline 3 & $60-70$ & Cukup \\
\hline 4 & $71-85$ & Baik \\
\hline 5 & $86-100$ & Sangat Baik \\
\hline
\end{tabular}

\section{ANALISIS DAN PEMBAHASAN}

Uji coba lapangan dilakukan di kelas IV SDN 02 Beduai. Pada media pembelajaran Mobuya pengembang memberikan buku panduan sebagai tuntunan bagi penggunaan media pembelajaran Mobuya, RPP, Silabus, Soal Soal evaluasi berbentuk essay, selanjutnya pegembang memberikan media pembelajaran Mobuya kepada guru dan kemudian memberikan angket penilaian kepada guru kelas. Pengembang atau guru model mengajar menggunakan media yang telah dikembangkan yaitu media pembelajaran Mobuya dan siswa menggunakan media secara berkelompok dengan bimbingan pengembang atau guru model. Siswa juga diberi buku panduan penggunaan media pembelajaran dengan tujuan untuk memberikan kemudahan kepada peserta didik dalam menggunakan media pembelajaran Mobuya. Hasil uji coba lapangan dapat dilihat pada Tabel 2 berikut:

Tabel 2. Hasil Angket Uji Coba Lapangan

\section{No Sub Indikator}

1. Apakah menurutmu media pembelajaran Mobuya cocok 23 untuk pembelajaran di kelas

2. Apakah media pembelajaran Mobuya memudahkanmu untuk 23 memahami materi pelajaran mengenai indahnya keragaman budaya negeriku

\section{Skala Penilaian YA (A) TIDAK (B)} 0

0 
3. Apakah media pembelajaran Mobuya menarik dan $23 \quad 0$ menyenangkan

4. Apakah media pembelajaran Mobuya memberikankanmu 23 pengetahuan mengenai keragaman budaya

5. Apakah dengan menggunakan media pembelajaran Mobuya 23 kamu mampu untuk memahami pelajaran mengenai indah keberagaman budaya di negeriku

6. Apakah dengan menggunakan media pembelajaran Mobuya 19 kamu mampu untuk memahami pelajaran mengenai indah keberagaman budaya di negeriku

7. Apakah dengan adanya media pembelajaran Mobuya ini 21 membuatmu merasakan mudah untuk mememahami pelajaran

8. Apakah kamu setuju jika media pembelajaran Mobuya ini 21 diajarkan di sekolah dasar

9. Media pembelajaran Mobuya membuat keingintahuan 23 terhadap pelajaran mengenai indahnya keragaman budaya di negeriku meningkat

10. Apakah kamu setuju bahwa media pembelajaran Mobuya 22 menyenangkan dan memudahkan untuk memahami pelajaran mengenai indah keragaman budaya di negeriku

11. Apakah kamu setuju jika media pembelajaran Mobuya ini 21

12. dapat meningkatkan hasil belajarmu

Apakah kamu senang belajar dengan media pembelajaran 21 Mobuya

13. Apakah materi yang diberikan kepadamu, mudah untuk kamu 22 pahami

14. Apakakah media pembelajaran sangat mudah untuk 21 dimainkan dan memberikan pengetahuan baru kepada kamu

15. Apakah peraturan yang ada pada media pembelajaran 22 Mobuya juga mudah dipahami

Jumlah

Berdasarkan hasil uji coba lapangan pada media pembelajaran Mobuya di peroleh persentase sebesar 95, 83\%. Data yang diperoleh tersebut di lakukan konversi diperoleh kriteria sangat layak.

Analisis yang dilakukan berikutnya dengan melakukan pada hasil evaluasi dalam proses pembelajara. Hasil evaluasi ini digunakan untuk mengukur keefektifan media. Hasil belajar siswa diperoleh melalui mengerjakan soal essay.

Tabel 3. Hasil Evaluasi Terhadap Penggunaan Media Pembelajaran Mobuya

\begin{tabular}{|c|c|c|c|c|}
\hline No & Nama & Nilai tes pertemuan I & Nilai tes pertemuan II & Keterangan \\
\hline 1. & $\mathrm{~A}$ & 50 & 60 & Tidak Tuntas \\
\hline 2. & $\mathrm{~B}$ & 70 & 75 & Tuntas \\
\hline 3. & $\mathrm{C}$ & 60 & 75 & Tuntas \\
\hline 4. & $\mathrm{D}$ & 65 & 70 & Tuntas \\
\hline 5. & $\mathrm{E}$ & 70 & 70 & Tuntas \\
\hline 6. & $\mathrm{~F}$ & 40 & 45 & Tidak Tuntas \\
\hline 7. & G & 60 & 70 & Tuntas \\
\hline 8. & $\mathrm{H}$ & 50 & 70 & Tuntas \\
\hline 9. & I & 70 & 70 & Tuntas \\
\hline 10. & $\mathrm{~J}$ & - & - & - \\
\hline 11. & $\mathrm{~K}$ & 60 & 65 & Tuntas \\
\hline 12. & $\mathrm{~L}$ & 65 & 70 & Tuntas \\
\hline 13. & M & 40 & 70 & Tuntas \\
\hline
\end{tabular}




\begin{tabular}{|c|c|c|c|c|c|}
\hline No & Nama & & Nilai tes pertemuan I & Nilai tes pertemuan II & Keterangan \\
\hline 14. & & $\mathrm{~N}$ & 70 & 75 & Tuntas \\
\hline 15. & & 0 & 50 & 55 & Tidak Tuntas \\
\hline 16. & & $\mathrm{P}$ & 50 & 70 & Tuntas \\
\hline 17. & & $\mathrm{Q}$ & 60 & 65 & Tuntas \\
\hline 18. & & $\mathrm{R}$ & 60 & 75 & Tuntas \\
\hline 19. & & S & 55 & 70 & Tuntas \\
\hline 20. & & $\mathrm{~T}$ & 60 & 65 & Tuntas \\
\hline 21. & & $\mathrm{U}$ & 60 & 70 & Tuntas \\
\hline 22. & & $\mathrm{~V}$ & 65 & 75 & Tuntas \\
\hline 23. & & W & 70 & 75 & Tuntas \\
\hline 24. & & $\mathrm{X}$ & 50 & 60 & Tidak Tuntas \\
\hline \multicolumn{3}{|c|}{ Jumlah } & 1350 & 1565 & \multirow{2}{*}{$\begin{array}{l}\text { Tuntas } \\
\text { Tuntas }\end{array}$} \\
\hline & Rata-Rata & & 58,70 & 68,04 & \\
\hline
\end{tabular}

Berdasarkan Tabel 3 di atas, terdapat peningkatan nilai rata-rata dari evaluasi terhadap hasil belajar yang dilakukan oleh peserta didik. Semua siswa kelas IV dikategorikan tuntas belajar.

Media pembelajaran Mobuya di gunakan dalam rangka menciptakan pembelajaran tematik di sekolah dasar yang menyenangkan dan memberikan kemudahan dalam proses pembelajaran bermakna. Sejalan dengan itu Majid (2017)bahwa belajar melalui kegiatan nyata peserta didik dapat memperoleh pengalaman belajar yang bermakna dan menyenangkan. Melalui pembejaran dengan media pembelajaran Mobuya dapat menjembatani. Media pembelajaran mampu menjebatani pembelajaran peserta didik (Majid, 2017). Sehingga tercipta pembelajaran yang menyenangkan, aktif serta kreatif.

Penerapan media pembelajaran Mobuya didasarkan pada spesifikasi produk yang di kembangkan berupa mengenalkan keberagaman budaya daerah sanggau. Media pembelajaran Mobuya di kategorikan sebagai media permainan papan (board game). Permainan papan (board game) merupakan alternatif media pembelajaran karena dengan bermain sesuai dengan karakteristik peserta didik (Hedman, 2011). Bedasarkan penelitian Latief, et al (2017) melalui media pembelajaran papan permainan papan (board game) memberikan pembelajaran menyenangkan sehingga tidak monoton. Melalui media pembelajaran Mobuya sesuai dengan karakteristik peserta didik karena dengan permainan papan (board game) sehingga akan memudahkan peserta didik untuk memahami pembelajaran di sekolah.

Penggunaan kartu pada proses kegiatan pembelajaran memberikan pembelajaran yang bermakna dan memberikan menguatkan konsep belajar peserta didik. Hal ini sejalan temuan Oktavianti \& Ratnasari (2017) kartu-kartu pada media pembelajaran permainan papan (board game) dapat menciptakan pemahaman peserta didik dalam memahami konsep pembelajaran tematik untuk mengenalkan keberagaman budaya. Hal ini sejalan dengan hasil temuan dalam penelitian ini bahwa dengan kartu pertanyaan banyak peserta didik merasa senang dan merasa belajar terasa lebih bermakan. Namun, selain itu penggunaan kartu juga dirasakan adanya kebosannan dalam proses pembelajaran hal ini karena penggunaan kartu berupa pertanyaan yang membuat peserta didik jenuh, untuk peserta didik usia pada tahap bermain harunya lebih sederhana sehngga akan memberikan pembelajaran yang benar-benar joyfull learning kepada peserta didik, sehingga pembelajaran yang dilaksanakan.

Proses pembelajaran dengan media pembelajaran Mobuya untuk pembelajaran tematik di sekolah dasar ditemukan bahwa melalui penggunaan media pembelajaran Mobuya terlihat dengan belajar sambil bermain dapat menciptakan pembelajaran yang menyenangkan. Hal ini sejalan dengan pendapat Majid (2017) menyebutkan bahwa melalui belajar sambil bermain dapat menciptakan belajar yang menyenangkan untuk peserta didik. Selanjutnya dari proses pembelajaran yang dilakukan pada saat proses uji coba lapangan yang dilakukan oleh peneliti terlihat peserta didik bergembira belajar sambil bermain dengan media pembelajaran. Hal ini sejalan dengan prinsip belajar yaitu belajar sambil bermain dimana dapat menimbulkan suasana yang menyenangkan bagi peserta didik dalam proses pembelajaran dengan bermain sambil belajar peserta didik dapat meningkatkan keterampilan, sikap, dan sehingga adanya daya fantasi belajar anak berkembang mendorong anak menjadi aktif kemapuan untuk memecahkan masalah Susanto (2014) belajar sambil bermain merupakan salah satu langkah yang dapat diterapakn sebagai alternatif media pembelajaran berupa media pembelajaran Mobuya.

Melalui penggunaan media pembelajaran Mobuya mampu memberikan guru solusi dalam proses pembelajaran disekolah dasar, sehingga pembelajaran dapat dilaksanak dengan efektif dan efisien. Pembelajaran dengan media pembelajaran Mobuya juga mampu meningkatkan proses pembelajaran pengenala keragaman budaya Negeriku di sekolah dasar. 
Jadi berdasarkan hasil dan teori terlihat bawah media pembelajaran Mobuya dapat dijadi alternatif media pembelajaran yang menyenangkan, sehingga pembelajaran yang dilaksanakan menjadi aktif, kreatif, peserta didik diberikan pesan mengenai indahnya memiliki keragaman budaya. Melalui media pembelajaran mobuya juga mampu memberikan keterampilan, sikap, sehingga mampu meningkatkan daya fantasi peserta didik. Melalui media pembelajaran mampu meningkatkan kesatuan dan persatuan. Media pembelajaran mobuya juga meningkatkan aktifitas peserta didik dalam kegiatan pembelajaran.

Pada proses penerapan media pembelajaran mobuya masih didapat beberapa kendala yang perlu untuk di lakukan perbaikan 1) Pengaturan posisi kelompok sebaiknya harus di atur sebelum pelaksanaan pembelajaran dengan media pembelajaran Mobuya; 2) pengaturan waktu yang harus diperhitungkan sehingga proses pembelajaran dapat dilaksanakan dengan efisien; 3) Kartu yang digunakan pada media pembelajaran masih perlu untuk dilakukan revisi berupa lebih mengenalkan keragaman budaya yang ada di daerah; 4) penggunaan media pembelajaran di dalam kelas harus lebih memahami karakteristik peserta didik yang ada pada tempat yang akan diterapkan; 5) pengaturan jadwal yang akan digunakan; 6) sebaiknya media pembelajaran Mobuya dilakukan dengan bermain peran; 7) Materi sebaiknya di paparkan sedikit pada proses pembelajaran untuk memberikan apersepsi pada peserta didik.

\section{KESIMPULAN}

Berdasarkan hasil uji coba lapangan pada media pembelajaran Mobuya di peroleh persentase sebesar 95, 83\%. Data yang diperoleh tersebut di lakukan konversi diperoleh kriteria sangat layak. Dilihat dari presentases rata-rata dari penggunaan media pembelajaran Mobuya untuk pembelajaran keragaman budaya didapatkan nilai rata-rata pada tes I 58,70 dan tes II diperoleh 68,04, terlihat ada perubahan hasil dari pelaksanaan pembelajaran dengan menggunakan media pembelajaran Mobuya. Serta terdapat peningkatan nilai rata-rata dari evaluasi terhadap hasil belajar yang dilakukan oleh peserta didik. Semua siswa kelas IV dikategorikan tuntas belajar.

Jika dilihat dari aspek peserta didik media pembelajaran efektif sebagai media pembelajaran ini berdasarkan pengamatan berdasarkan angket bahwa media pembelajaran efektif untuk diterapkan. Jika dilihat berdasarkan aspek kurikulum bahwa media pembelajaran sesuai dengan kompetensi dasar dan tujuan pembelajaran ini dapat dilihat dari uji validasi terhadap materi oleh ahli. Selanjutnya bila dilihat dari aspek penilaian bahwa media pembelajaran dapat menjadi alternatif media pembelajaran karena mampu memberikan pembelajaran yang menyenagkan dapat dilihat dari hasil tes pertemuan pertama yang dilakukan masih belum mengalami perubahan pembelajaran dan dipertemuan kedua sudah mengalami perubahan yang sangat signifikan. Berdasarkan uji coba yang telah dilakasanakan pada proses pembelajaran didapatkan pada media pembelajaran Mobuya peserta didik masih susah untuk membuka kartu media pembelajaran mobuya sehingga masih perlu untuk disederhanakan kembali, selain itu peserta didik masih mengeluhkan untuk materi yang diberikan terlalu panjang. Media pembelajaran Mobuya juga terdapat beberapa kendalan dalam proses penerapannya, berupa siswa masih tidak fokus pada media pembelajaran namun media pembelajaran ini siswa tidak terarah sesuai materi. Sehingga media pembelajaran Mobuya perlu untuk dilakukan fokus pada guru agar lebih menyenangkan. Namun secara keseluruhan media pembelajaran ini sudah mampu memberikan pembelajaran yang menyenagkan dan bermakna.

Melalui media pembelajaran Mobuya memliki taraf signifikasi terhadap hasil pembelajaran sehingga dapat disimpulkan bahwa dengan media pembelaran mampu meningkatakan hasil belajar serta dapat dijadikan media pembelajaran. Media pembelajaran dapat disimpulkan layak untuk digunakan pada proses pembelajaran.

\section{DAFTAR PUSTAKA}

Asist, R., \& Sezer, B. (2013). Integrating Technology Into Classroom : The Learner-Centered Instructional Design, (October), 134-144.

Branch, R. M. (2009). Instructional Design: The ADDIE Approach. New York Dordrecht Heidelberg London: Springer. https://doi.org/10.1007/978-0-387-09506-6

D'Astous, A., \& Gagnon, K. (2007). An inquiry into the factors that impact on consumer appreciation of a board game. Journal of Consumer Marketing, 24(2), 80-89. https://doi.org/10.1108/07363760710737085

Fitriyawany. (2013). Penggunaan Media Permainan. Jurnal Ilmiah DIDAKTIKA, XIII(2), 223-239.

Halloran, R. O., Deale, C., Halloran, R. O., Ph, D., Deale, C., \& Ph, D. (2017). Designing a Game Based on 
Monopoly as a Learning Tool for Lodging Development Designing a Game Based on Monopoly as a Learning Tool for Lodging Development, 3758(October). https://doi.org/10.1080/10963758.2010.10696983

Hedman, E. (2011). The Frustration of Learning Monopoly: The Emotional Tension of Entering a New Game Encounter. The Ethnographic Praxis in Industry Conference, Boulder, (2001), 18-21.

Latief, M., Kimia, J., \& Makassar, U. N. (2017). PENGEMBANGAN PERMAINAN ULAR JARRA SEBAGAI MEDIA, 20, 101-107.

Macdonald, A. (2014). Student demands and a thematic approach to teaching and learning at the University College of Education in Iceland in 1978, 1-19.

Majid, A. (2017). Pembelajaran Tematik Terpadu. Bandung: Remaja Rosdakarya.

Oktavianti, Ika \& Ratnasari, Y. (2017). PERMAINAN MONOPOLI ENGKLEK JELAJAH BUDAYA PATI UNTUK PEMBELAJARAN TEMATIK. Pendidikan Bahasa Dan Sastra Indonesia (PBSI) FKIP Universitas Muria Kudus, 63-71.

Park, J. W. (2017). Hybrid Monopoly: A Multimedia Board Game that Supports Bidirectional Communication between a Mobile Device and a Physical Game Set. Multimedia Tools and Applications, 76(16), 17385-17401. https://doi.org/10.1007/s11042-017-4589-x

Retnawati, H., \& Munadi, S. (2017). Teachers ' Difficulties in Implementing Thematic Teaching and Learning in Elementary Schools, (2012). https://doi.org/10.15804/tner.2017.48.2.16

Sugeng. (2018). Mengagumi Budaya Lokal Dari Kabupaten Sanggau Nyeser Prosesi Temiang Taba Mengusir Hantu. Retrieved from http://pontianpost.co.id/ Mengagumi-Budaya-Lokal-DariKabupaten-Sanggau-Nyeser-Prosesi-Temiang-Taba-Mengusir-Hantu

SUHENDRIANTO. (2017). PENGEMBANGAN MEDIA PEMBELAJARAN MONOPOLI TEMATIK UNTUK MENINGKATKAN MOTIVASI BELAJAR Tesis Tesis.

Sukini. (2012). Pembelajaran Tematik di Sekolah Dasar Kelas Rendah dan Pelaksanaannya. Klaten: Universitas Widya Dharma.

Susanto, A. (2014). Pengembangan Pembelajaran IPS di Sekolah Dasar. Jakarta: Kencana.

Utami, S. E. (2015). Strategi Pembelajaran Tematik, 2(November).

Wangid, M. N., Mustadi, A., Erviana, V. Y., \& Arifin, S. (2014). Kesiapan guru SD dalam pelaksanaan pembelajaran tematik-integratif pada kurikulum 2013 di DIY. Jurnal Prima Edukasia, 2(2), 175-182. https://doi.org/10.21831/jpe.v2i2.2717

Yong, C. Y., Chew, K. M., Mahmood, N. H., \& Ariffin, I. (2014). Image Processing Tools Package in Medical Imaging in MATLAB, (May). 